Utah State University

DigitalCommons@USU

$1-2-2020$

\title{
Early Goose Arrival Increases Soil Nitrogen Availability More Than an Advancing Spring in Coastal Western Alaska
}

\author{
Ryan T. Choi \\ Utah State University \\ Karen H. Beard \\ Utah State University \\ Katharine C. Kelsey \\ University of Colorado Denver \\ A. Joshua Leffler \\ South Dakota State University \\ Joel A. Schmutz \\ U.S. Geological Survey Alaska Science Center \\ Jeffrey M. Welker \\ University of Alaska-Anchorage \\ Follow this and additional works at: https://digitalcommons.usu.edu/eco_pubs \\ Part of the Ecology and Evolutionary Biology Commons
}

\section{Recommended Citation}

Choi, R.T., Beard, K.H., Kelsey, K.C. et al. Early Goose Arrival Increases Soil Nitrogen Availability More Than an Advancing Spring in Coastal Western Alaska. Ecosystems (2020). https://doi.org/10.1007/

s10021-019-00472-9

This Article is brought to you for free and open access by the Ecology Center at DigitalCommons@USU. It has been accepted for inclusion in Ecology Center Publications by an authorized administrator of DigitalCommons@USU.

For more information, please contact

digitalcommons@usu.edu.

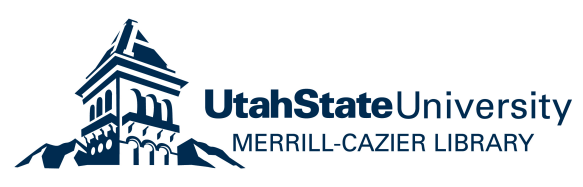


Title: Early goose arrival increases soil nitrogen availability more than an advancing spring in coastal western Alaska

Running head: Soil nitrogen response to phenological mismatch

Authors: Ryan T. Choi ${ }^{1}$, Karen H. Beard ${ }^{1}$, Katharine C. Kelsey ${ }^{2,3}$, A. Joshua Leffler ${ }^{4}$, Joel A. Schmutz ${ }^{5}$, Jeffrey M. Welker²,6

${ }^{1}$ Department of Wildland Resources, Utah State University and the Ecology Center, Logan, UT 84322-5230 USA

${ }^{2}$ Department of Biological Sciences, University of Alaska-Anchorage, Anchorage, AK 99508

USA

${ }^{3}$ Geography and Environmental Science Department, University of Colorado Denver, Denver, CO 80217

${ }^{4}$ Department of Natural Resource Management, South Dakota State University, Brookings, SD 57006 USA

${ }^{5}$ U.S. Geological Survey Alaska Science Center, Anchorage, AK 99508 USA

${ }^{6}$ UArctic, Ecology and Genetics Research Unit, University of Oulu, Oulu, Finland

Corresponding Author: Karen H. Beard, karen.beard@usu.edu, 1-435-797-8220

Paper Type: Research Article

Author contributions: KHB, JMW, AJL, and JAS conceived and designed the experiment. RTC and KCK performed the experiment. RTC analyzed the data. RTC and KHB wrote the manuscript; other authors contributed editorial advice. 


\section{ABSTRACT}

2 An understudied aspect of climate change-induced phenological mismatch is its effect on 3 ecosystem functioning, such as nitrogen $(\mathrm{N})$ cycling. Migratory herbivore arrival time may alter

$4 \quad \mathrm{~N}$ inputs and plant-herbivore feedbacks, while earlier springs are predicted to increase $\mathrm{N}$ cycling rates through warmer temperatures. However, the relative importance of these shifts in timing

6 and how they interact to affect $\mathrm{N}$ cycling are largely unknown. We conducted a three-year

7 factorial experiment in coastal western Alaska that simulated different timings of Pacific black

8 brant (Branta bernicla nigricans) arrival (3-weeks early, typical, 3-weeks late, or no-grazing)

9 and the growing season (ca. 3-weeks advanced and ambient) on adsorbed and mobile inorganic

$10\left(\mathrm{NH}_{4}^{+}-\mathrm{N}, \mathrm{NO}_{3}{ }^{-}-\mathrm{N}\right)$, and mobile organic $\mathrm{N}$ (amino acid) pools. Early grazing increased $\mathrm{NH}_{4}^{+}-\mathrm{N}$,

$11 \mathrm{NO}_{3}^{-}-\mathrm{N}$, and amino acids by $103 \%, 119 \%$, and $7 \%$, respectively, while late grazing reduced

12 adsorbed $\mathrm{NH}_{4}{ }^{+}-\mathrm{N}$ and $\mathrm{NO}_{3}{ }^{-}-\mathrm{N}$ by $16 \%$ and $17 \%$, respectively. In comparison, the advanced

13 growing season increased mobile $\mathrm{NH}_{4}{ }^{+}-\mathrm{N}$ by $26 \%$. The arrival time by geese and the start of the

14 season did not interact to influence soil $\mathrm{N}$ availability. While the onset of spring in our system is

15 advancing at twice the rate of migratory goose arrival, earlier goose migration is likely to be

16 more significant than the advances in springs in influencing soil N, although both early goose

17 arrival and advanced springs are likely to increase $\mathrm{N}$ availability in the future. This increase in

18 soil $\mathrm{N}$ resources can have a lasting impact on plant community composition and productivity in

19 this N-limited ecosystem.

21 Key words: Carex subspathacea; global change ecology; migration timing; nitrogen; Pacific

22 black brant; phenological mismatch; plant-herbivore interactions; trophic mismatch. 


\section{HIGHLIGHTS:}

25 1. Soil $\mathrm{N}$ increased with early goose grazing and decreased with late grazing.

262 . Combined early goose arrival and season advancement lead to greater soil N.

27 3. Early grazing had a greater influence on soil $\mathrm{N}$ than an advanced growing season.

\section{INTRODUCTION}

Northern latitudes are experiencing rapid warming and spring advancement, which is

31 altering the timing of biological interactions, especially for long-distance migratory species

32 (Cohen and others 2018; Renner and Zohner 2018). While some species, such as migratory

33 geese, have started to shift the timing of their migration earlier in response to climate-induced

34 season advancement (Kölzsch and others 2015; Boelman and others 2017), there is still potential

35 for resource-consumer 'phenological mismatch' due to the different rates of climatic change in

36 their winter and summer ranges (Lameris and others 2017; Mayor and others 2017).

37 Phenological mismatch between long-distance migratory birds and their resources is already

38 negatively affecting higher trophic herbivores through reductions in resource availability and

39 forage quality (Doiron and others 2015; Ross and others 2017). While it is unclear if the

40 mismatch will persist, it is likely that these mismatches will have long-term consequences for

41 some northern systems due to the rapid occurrence of change in the Arctic (Miller-Rushing and

42 others 2010). An understudied aspect of phenological mismatch is how ecosystem-level

43 processes, such as nutrient cycling, may be impacted (Kelsey and others 2018; Heberling and

44 others 2019; Leffler and others 2019), and until recently this has been largely overlooked (Beard 45 and others 2019b). 
Investigating how developing phenological mismatch influences soil nitrogen $(\mathrm{N})$ availability is fundamental for understanding how northern latitudes are changing because $\mathrm{N}$ is often a limiting resource for plant growth in these systems (Schimel and others 1996). Shifts in the timing of trophic interactions (i.e., changes in herbivory) and subsequent $\mathrm{N}$ inputs (i.e., litter, feces) may alter soil $\mathrm{N}$ available for plant uptake and microbial immobilization over the brief summer growing season (Ruess and others 1997); however, the direction or magnitude of these responses is uncertain. Because plant growth is highly coupled to N availability (Grogan and Zamin 2018), climate-induced changes to inorganic $\left(\mathrm{NH}_{4}{ }^{+}-\mathrm{N}, \mathrm{NO}_{3}{ }^{-}-\mathrm{N}\right)$ and organic $\mathrm{N}$ (amino acid) pools can directly alter ecosystem functioning, including changes in plant productivity and microbial respiration (Belay-Tedla and others 2009; Sistla and others 2012; Schaeffer and others 2013), or even lead to ecosystem loss of $\mathrm{N}$ through leaching or denitrification (Buckeridge and

others 2010; Martinsen and others 2012) (Figure 1). Determining the effects of resourceconsumer phenological mismatch on $\mathrm{N}$ cycling requires investigating shifts in the timing of the consumer (i.e., herbivory) and shifts in the timing of the resource (i.e., plant growing season) as separate temporal controls.

The first critical temporal controls are changes in the seasonal timing of herbivory (Clausen and Clausen 2013; Lameris and others 2017). Migratory geese, for example, are arriving earlier to their Arctic breeding grounds, but some species are not arriving early enough to match the advanced rate of plant green-up (Doiron and others 2015; Ross and others 2017). The timing of migratory goose arrival is expected to be particularly important to $\mathrm{N}$ cycling, especially in the coastal Arctic where geese occur at high densities and function as ecosystem engineers (e.g. Uher-Koch and others 2019). Goose herbivory has the ability to affect $\mathrm{N}$ cycling in three ways: the direct removal of aboveground tissue through grazing, the addition of soluble 
$\mathrm{N}$ through fecal deposition, and the trampling of standing dead litter into the soil promoting the turnover of organic material and rapid decomposition (Bazely and Jefferies 1989; Ruess and others 1997; Zacheis and others 2002). Previous work found that early goose grazing reduced above- and belowground plant biomass while later arrival and grazing had the opposite effect (Choi and others 2019). The changing arrival time of geese also alters the timing of goose fecal inputs, which can be an important source of soluble organic N (Henry and Jefferies 2002). Based on our understanding of how the timing of goose herbivory influences vegetation, and the ability of coastal graminoids to utilize amino acids and inorganic $\mathrm{N}$ forms (Henry and Jefferies 2003; to alter both organic and inorganic $\mathrm{N}$ availability (Figure 1).

The second temporal controls are changes in climate-driven shifts in the resource, most often through advancement of the growing season and resulting higher rates of soil $\mathrm{N}$ cycling $(\mathrm{N}$

81 mineralization $\left[\mathrm{N}_{\min }\right]$, ammonification, denitrification) (Buckeridge and Grogan 2010; Bardgett and others 2013). Warmer soil temperatures from season advancement can stimulate microbial enzymatic activity (Sistla and Schimel 2013), which can increase soil $\mathrm{NH}_{4}{ }^{+}-\mathrm{N}$ and $\mathrm{NO}_{3}{ }^{-}-\mathrm{N}_{\text {pools, }}$, and gaseous N efflux (Blankinship and Hart 2012; Bai and others 2013). Earlier springs can also increase the labile organic N pool and amino acids (Darrouzet-Nardi and others 2019), which are an important source of $\mathrm{N}$ for coastal graminoids in Arctic systems (Henry and Jefferies 2003). However, advanced growing seasons also increase plant growth and demand (Lin and others 2010), thereby reducing $\mathrm{N}$ pools through greater plant uptake (Natali and others 2012) and microbial immobilization (Jonasson and others 1999). Because of the microbial response to earlier warmer temperatures and extension of the growing season, we predict that season

91 advancement will mobilize more soil $\mathrm{N}$ than can be assimilated by plant growth. 
There is a growing climate-driven phenological mismatch between the timing of

93 herbivory by wild geese and the timing of the growing season, and a gap in our knowledge of

94 how changes in the relative importance of these processes influence $\mathrm{N}$ cycling and soil $\mathrm{N}$ pools.

95 To address this, we conducted a three-year field experiment that manipulated the timing of

96 migratory goose arrival (early, typical, late, and no arrival) and the growing season (advanced

97 and ambient). We then measured how the timing of these events and their interactions influence

98 inorganic $\left(\mathrm{NH}_{4}{ }^{+}-\mathrm{N}, \mathrm{NO}_{3}{ }^{-}-\mathrm{N}\right)$ and organic (amino acid) soil $\mathrm{N}$ pools and $\mathrm{N}_{\min }$ rates. We

99 hypothesized that: H1) early goose arrival results in larger inorganic and organic N pools earlier

100 in the season because early goose grazing reduces above- and belowground plant biomass (Choi

101 and others 2019) and initiates earlier fecal inputs and trampling, while late migration has the

102 opposite effect (Figure 1); H2) season advancement and associated early season soil warming

103 stimulate microbial net $\mathrm{N}$ mobilization (i.e. the production and release of organic $\mathrm{N}$ and

104 inorganic $\mathrm{N}_{\min }$ ), which outweighs any reduction from early season plant growth (Leffler and

105 others 2019), and results in larger inorganic N pools compared to an ambient season; and H3) the

106 interaction between earlier goose arrival and season advancement synergistically increase pools

107 of inorganic and organic $\mathrm{N}$ because of the combined effect from warmer soil temperatures and

108 earlier grazing, feces, and trampling.

109

110 METHODS

111 Study site

112 We conducted this study near the Tutakoke River in the central coastal region of the

113 Yukon-Kuskokwim (Y-K) Delta in western Alaska $\left(61^{\circ} 15^{\prime} \mathrm{N}, 165^{\circ} 37^{\prime} \mathrm{W}\right.$; elevation $\left.2 \mathrm{~m}\right)$. The Y-

$114 \mathrm{~K}$ Delta is over $125,000 \mathrm{~km}^{2}$ of coastal tundra between the Yukon and Kuskokwim Rivers along 
115 the Bering Sea. We established experimental plots within $1 \mathrm{~km}$ of the coast in a wet sedge

116 meadow on the active floodplain. Climate in the area is moderated by the Bering Sea with mean

117 temperatures ranging from -14 to $10^{\circ} \mathrm{C}$ in midwinter and summer, respectively (Jorgenson and

118 Ely 2001).

119 Soils at our site are saturated and brackish, often mesohaline $\left(8,000-30,000 \mu \mathrm{S} \mathrm{m}^{-1} ; 0.5\right.$ -

$12018 \mathrm{ppt}$ ), frequently inundated by monthly tides, and characterized by interbedded layers of silt

121 and sandy loams (Jorgenson 2000). Permafrost, while found further inland, is not present in the

122 active coastal floodplain. Soils are classified as histosols and have a bulk density of $0.69 \mathrm{~g} \mathrm{~cm}^{-3}$,

123 and $9.5 \%$ organic content consisting of $4.7 \% \mathrm{C}$ and $0.3 \% \mathrm{~N}$.

124 Carex graminoids are the dominant vegetation in the coastal Y-K Delta. C. subspathacea, 125 in particular, is a critically important goose forage species, that occurs in near monotypic stands 126 along the margins of ponds and tidal flats, and is so heavily grazed and modified by geese that 127 when altered, it is referred to as 'grazing lawn' (Person and others 2003). Using the day of year 128 when NDVI (normalized difference vegetation index) reaches 50\% of its maximum as a 129 vegetation phenology metric (Brook and others 2015), green-up has varied over 30 days (23-May 130 to 25-June) over the last 35 years (1982-2016), but has occurred on average 0.3 days earlier per 131 year (Leffler and others 2019).

132 Geese time their long-distance migration to optimize their nutrient demands with a 133 narrow window of peak nutrient availability in the spring (Sedinger and Raveling 1986).

134 Approximately 50\% of the world's Pacific black brant (Branta bernicla nigricans) nest in the 135 coastal Y-K Delta, with ca. 30-day variation in the range of hatch dates (3-June to 9-July) 136 observed over 34 years (1983-2016) (Fischer and others 2008, 2017). However, the three years 137 of our experiment $(2014,2015,2016)$ had three of the earliest six hatch dates for black brant in 
138 the Y-K Delta, especially year 3 (2016), which was the earliest on record (Fischer and others

139 2017). At our site, there is a positive correlation between NDVI spring advancement and hatch

140 date $\left(\mathrm{R}^{2}=0.78\right)$, but geese do not appear able to keep up with the timing of spring with

141 migratory arrival occurring on average 0.14 days earlier per year (Fischer and others 2017).

143 Phenology experiment

144 We conducted a three-year fully factorial experiment simulating scenarios of

145 phenological mismatch. This experiment has been used to investigate changes in greenhouse gas

146 flux (Kelsey and others 2018; Leffler and others 2019), forage quality (Beard and others 2019a)

147 and plant traits (Choi and others 2019) and is described in those studies. Briefly, we used four

148 timings of grazing (early, typical, late, and no-grazing) crossed with two timings of the growing

149 season (advanced and ambient) for a total of eight treatments. We altered the timing of goose

150 grazing by minus-three, zero, and plus-three weeks (early, typical, and late treatments,

151 respectively), and advanced the growing season by three weeks (see below). The 'typical' goose

152 treatment represented historic mean arrival and grazing and acted as the grazing treatment

153 control, while the 'no-grazing' treatment represented potential future scenarios where goose

154 populations decline to near zero or fail to arrive. We also had a background grazing control plot

155 in each block that was used to compare the effectiveness of our experimental grazing, but not as

156 a statistical comparison for our treatments. Thus, we had a total of 54 plots in six replicate blocks

157 located within $700 \mathrm{~m}$. All plots were established in April 2014 and were $1.7 \mathrm{~m} \mathrm{x} 0.85 \mathrm{~m}$ in size.

158 We installed fencing around all paired advanced and ambient growing season plots, except the

159 background grazing control, to exclude wild goose grazing. Treatments were assigned randomly

160 and applied to the same plots from 1-May through 15-August each year. 
We manipulated timing of grazing by introducing wild-caught geese into fenced goose

162 exclosures (ca. $7.6 \mathrm{~m}^{2}$ ) at specific times during the season. Early, typical and late grazing

163 treatments began on 30-May, 20-June, and 9-July, respectively, to approximate the 30-day

164 variation in the range of historic mean hatch dates (3-June to 9-July) (Fischer and others 2017).

165 These dates are the biologically relevant means for our system and allowed us to use actual geese

166 (as opposed to simulated grazing) in our experiments, which required treatments to start after

167 nest initiation so they could be captured. Aboveground biomass in background control plots did

168 not differ from typical grazing plots in years 1 and 2 or early goose grazing plots for all three

169 years (Choi and others 2019). Because the experiment coincided with three of the six earliest

170 mean hatch dates in the Y-K Delta over the last 34 years and the last year of our experiment was

171 the earliest on record (Fischer and others 2017), we expected that background controls would be

172 more similar to early goose grazing treatments by year 3.

173 Grazing treatments only differed in the timing of grazing initiation; we kept total grazing

174 time constant among treatments. While earlier shifts in migratory goose arrival might result in a

175 longer available season for grazing, the duration of time spent on Carex grazing lawns is

176 constrained by the development time of goslings, typically ca. 40 days (Sedinger and others

177 2001). Furthermore, differences in timing of grazing treatments are attributed to the timing of

178 grazing initiation, and not variation in the duration of grazing. Experimental grazing treatments

179 (early, typical, and late grazing) consisted of two brant geese grazing, trampling and defecating

180 inside exclosures during four $24 \mathrm{~h}$ bouts separated by 12 days over a total of 37 days to simulate

181 post-hatch grazing. Unlike other goose species in the Y-K Delta, black brant are grazers and do

182 not grub during the summer (Sedinger and Raveling 1984). Prior to each grazing treatment, we

183 held geese for two hours without food to allow feces from captive feeding to pass through their 
184 digestive system. After each $24 \mathrm{~h}$ grazing treatment, we held birds for an additional two hours to 185 collect feces which were returned to the appropriate plots. In between grazing treatments, we 186 held geese in a fenced enclosure and allowed them to graze freely on natural vegetation,

187 supplemented ad libitum with commercial goose feed. Captive geese were released into the wild 188 at the end of each season.

189 We used two adjacent conical passive-warming open-top chambers (OTCs; $30 \mathrm{~cm}$ height $190 \times 85 \mathrm{~cm}$ base dia. $\times 50 \mathrm{~cm}$ top dia.) to initiate an earlier growing season in the advanced season 191 plots. We placed OTCs on plots from 1-May to 1-July, and removed them only during goose 192 grazing treatments. We monitored air and soil temperature (10 $\mathrm{cm}$ above- and belowground $)$ 193 inside and outside OTCs in every plot each growing season. These OTCs doubled mean 194 vegetation height and advanced the growing season by 22, 18, and 21 days by the end of June 195 2014, 2015, and 2016, respectively (Leffler and others 2019). OTCs warmed plots on average 196 between 0.6 and $1.7^{\circ} \mathrm{C}$ (aboveground) and 0.6 and $1.0{ }^{\circ} \mathrm{C}$ (belowground).

\section{Soil N measurements}

199 We measured inorganic $\left(\mathrm{NH}_{4}{ }^{+}-\mathrm{N}, \mathrm{NO}_{3}{ }^{-}-\mathrm{N}\right)$ and organic $\mathrm{N}$ (amino acids) and $\mathrm{N}$

200 mineralization in all treatments of the experiment. Inorganic $\mathrm{N}\left(\mathrm{NH}_{4}^{+}-\mathrm{N}, \mathrm{NO}_{3}{ }^{-}-\mathrm{N}\right)$ was measured 201 via two methods, while organic N (amino acids) was measured via one method over three years. $202 \mathrm{~N}_{\min }$ was measured only during the third year of the experiment.

203 We used ion-exchange resin strips (2.5 $\mathrm{cm}$ wide x $10 \mathrm{~cm}$ length; CR67 \& AR204SZRA, 204 General Electricals, Watertown, MA) to measure inorganic $\mathrm{N}\left(\mathrm{NH}_{4}{ }^{+}-\mathrm{N}, \mathrm{NO}_{3}{ }^{-}-\mathrm{N}\right)$ available to 205 adsorb to soil particles (Qian and Schoenau 1995). We prepared cation and anion strips 206 separately using the same procedure. We immersed and shook strips in baths of $0.5 \mathrm{M} \mathrm{HCl}$ for 1 
$207 \mathrm{~h}$ and $0.5 \mathrm{M} \mathrm{NaHCO}_{3}$ for $5 \mathrm{~h}$, and then washed and stored them with deionized water. In the

208 center of each plot, we installed six to eight cation and anion resin pairs vertically $10 \mathrm{~cm}$ into the 209 ground until the top was even with the surface of the soil. We collected resins every two weeks, 210 each time yielding a cumulative measure of adsorbed inorganic N. Upon collection, we froze all 211 resins in the field. In the laboratory, we washed all resins using $50 \mathrm{~mL}$ of $2 \mathrm{M} \mathrm{KCl}$ and froze 212 extracts until analysis.

213 Because some of our plots experienced seasonal inundation during high tide events, we 214 used an additional resin approach to measure soil inorganic N. Seawater has a high ionic 215 potential and tidal flooding can interfere with measurements by striping resin ion-exchange sites 216 of adsorbed inorganic N (McBride 1989). High spring tides flooded and inundated several 217 experimental blocks each season (Julian date 2014 (205), 2015 (186), $2016(185,210)$ ), which 218 corresponded with a drop-off in resin-collected $\mathrm{N}$ on strips that remained in situ (Figure 2). To 219 address this problem in years 2 and 3, we installed intertidal resin sets for three weeks between 220 monthly peak tides, determined from regional NOAA tide predictions (Dall Point, AK;

221 tidesandcurrents.noaa.gov), and collected pairs from plots before the next peak tidal event. Both 222 cumulative and intertidal resin incubations had their own strengths and results show similar 223 trends, so we present both datasets for completeness. Resin measurements represent $\mathrm{N}$ adsorption 224 by soil ion-exchange sites over time, and separate resin collections are referred to as either 225 'cumulative' or 'intertidal'.

226 We used microlysimeters to measure labile inorganic $\left(\mathrm{NH}_{4}^{+}-\mathrm{N}, \mathrm{NO}_{3}{ }^{-}-\mathrm{N}\right)$ and organic $\mathrm{N}$ 227 (amino acids) pools in soil pore water. At the center of each plot, we installed a single 10-cm 228 rhizon soil moisture microlysimeter (Eijkelkamp, Giesbeek, Netherlands) perpendicular into the 229 soil surface and left them in place over the season. We used plastic syringes to collect $10 \mathrm{~mL}$ 
230 pore water samples from the top $10 \mathrm{~cm}$ of soil every two weeks, and used $1 \mu \mathrm{m}, 25-\mathrm{mm}$ diameter 231 Acrodisc glass fiber syringe filters (Pall Laboratory, Port Washington, NY) to pre-filter soil pore 232 water before storing and freezing samples until analysis. Microlysimeter measurements represent 233 labile $\mathrm{N}$ available in soil pore water at the time of collection.

234 During the final year of the experiment, we measured net $\mathrm{N}_{\min }$ rates in each experimental 235 plot $(\mathrm{n}=54)$ using the buried bag technique (Robertson and others 1999). On 1-June, we took 236 two, 4-cm diameter cores from the top $10 \mathrm{~cm}$ of soil in each plot. We collected one core and 237 placed the other intact in a polyethylene bag and buried it in situ until 1-August. We 238 homogenized, sieved, and extracted both cores within $24 \mathrm{~h}$ of collection. From each core, we 239 extracted $10 \mathrm{~g}$ of root-free soil in $50 \mathrm{~mL}$ of $2 \mathrm{M} \mathrm{KCl}$, filtered, and froze samples until analysis.

240 We calculated net $\mathrm{N}_{\min }\left(\mu \mathrm{g} \mathrm{N}\right.$ g-dry $\left.\operatorname{soil}^{-1} \mathrm{~d}^{-1}\right)$ as the difference in total $\mathrm{NH}_{4}{ }^{+}-\mathrm{N}^{-}$and $\mathrm{NO}_{3}^{-}-\mathrm{N}$ 241 between the initial harvest and final harvest divided by the total number of days in situ.

242 We analyzed filtrate from resin extracts, microlysimeter samples, and $\mathrm{N}_{\text {min }}$ measurements 243 using colorimetric $\left(\mathrm{NH}_{4}{ }^{+}-\mathrm{N}, \mathrm{NO}_{3}{ }^{-}-\mathrm{N}\right)$ or fluorometric (amino acid) microplate assays. We used 244 the Berlethot reaction for $\mathrm{NH}_{4}{ }^{+}-\mathrm{N}$ (Rhine and others 1998) and the Griess reaction for $\mathrm{NO}_{3}{ }^{-}-\mathrm{N}$ 245 (Doane and Horwáth 2003). We measured organic N (amino acid) using fluorescence of samples 246 with $o$-phthaldialdehyde and $\beta$-mercaptoethanol (Jones and others 2002). Absorbance and 247 fluorescence values were measured with a Synergy ${ }^{\mathrm{TM}} \mathrm{H} 4$ Hybrid Multi-Mode Microplate Reader 248 (Bio-Tek Inc., Winooski, VT) at Utah State University.

Statistical analysis

We tested the effects of timing of goose grazing (early, typical, late, no-grazing) and 252 timing of the growing season (advanced, ambient) on soil $\mathrm{N}$ availability. We used $\mathrm{NH}_{4}{ }^{+}-\mathrm{N}, \mathrm{NO}_{3}{ }^{-}$ 
$253-\mathrm{N}$ and amino acids, and $\mathrm{N}_{\min }$ measurements as continuous response variables, experimental

254 treatments (timing of goose grazing, start of the growing season), sampling date, and year as

255 fixed-effect predictor variables, and treated plot nested within block as a random effect. Separate

256 models were used for each measured $\mathrm{N}$ pool (cumulative and intertidal resin $\mathrm{NH}_{4}{ }^{+}-\mathrm{N}^{-}$and $\mathrm{NO}_{3}{ }^{-}-$

$257 \mathrm{~N}$, and microlysimeter $\mathrm{NH}_{4}{ }^{+}-\mathrm{N}, \mathrm{NO}_{3}{ }^{-}-\mathrm{N}$, and amino acids). We tested distributions of continuous

258 variables for normality and homogeneity of variance, and log-transformed all predictor variables

259 prior to analysis to meet these assumptions. We coded ambient season and typical grazing plots

260 as the reference comparison for the growing season and grazing season treatment, as appropriate.

261 Our models included interactions of fixed-effect predictors, but we limited interactions to

262 combinations of no more than two variables. We determined variable importance by inclusion in

263 the top-performing model. We included a first-order autocorrelation structure to account for

264 repeated measures within subjects over time.

265 For all analyses, we used a linear mixed model framework with model selection and

266 Akaike Information Criteria (AIC). We fit all models using the nlme package within the R

267 statistical computing environment (Pinheiro and others 2017, R Core Development Team). We

268 selected top models based on $\triangle \mathrm{AIC}$ and considered models to be similar if $\triangle \mathrm{AIC}<2$ (Burnham

269 and others 2011). Using the nlme summary function, we determined the fixed effect parameter

270 estimates for top model variables that were statistically different from the reference intercept

271 (ambient season, typical grazing) (Supplemental Table S1). For simplicity and to capture the

272 effects after three years of experimental treatments, we present soil $\mathrm{N}$ percent change as the

273 mean across the last year of the experiment unless otherwise indicated.

274

275 RESULTS 
Across all $\mathrm{N}$ pool measurements, both timing of grazing and timing of season were included in the top models highlighting the strength of timing of goose herbivory and season advancement treatments on soil $\mathrm{N}$ availability (Table 1). There were no interactions between the timing of grazing and timing of season in any of our top models.

Cumulative and intertidal ion-exchange resins and soil pore water in early grazing plots had $62 \%, 21 \%$ and $103 \%$ more $\mathrm{NH}_{4}{ }^{+}-\mathrm{N}$, respectively, compared to typical grazing treatment (Figs. 2-4). Intertidal resins had $16 \%$ less $\mathrm{NH}_{4}{ }^{+}-\mathrm{N}$ available in late grazing than typical grazing treatments (Figs. 3A-B). Comparatively, the advanced growing season had a 2\% and 26\% increase in intertidal and soil pore $\mathrm{NH}_{4}{ }^{-}-\mathrm{N}$ pools, respectively, compared to the ambient treatment by year 3 (Supplemental Table S1). The top-ranking models for resin-adsorbed soil $\mathrm{NH}_{4}{ }^{+}-\mathrm{N}$ included year, season advancement, and an interaction between timing of grazing and sampling date, whereas top-ranking models for $\mathrm{NH}_{4}^{+}-\mathrm{N}$ in soil pore water included timing of grazing, season advancement, and an interaction between year and sampling date (Table 1). Early grazing had seasonal peaks in intertidal resin-adsorbed $\mathrm{NH}_{4}{ }^{+}-\mathrm{N}$ that coincided with

291 late grazing delayed seasonal peak intertidal resin-adsorbed $\mathrm{NH}_{4}{ }^{+}-\mathrm{N}$ by $\sim 20$ days later in the 292 season compared to typical grazing plots (Figs. 3A-B), which coincided with the timing of late 293 grazing treatments ( 9-July to 15-August). Unlike early grazing, an advanced growing season 294 did not shift the peak timing of soil $\mathrm{NH}_{4}{ }^{+}-\mathrm{N}$ available for biological assimilation. Cumulative resin-adsorbed $\mathrm{NO}_{3}{ }^{-}-\mathrm{N}$ declined while intertidal resin and soil pore $\mathrm{NO}_{3}{ }^{-}-\mathrm{N}$ increased across the three years. Top models for resin-adsorbed and soil pore $\mathrm{NO}_{3}{ }^{-} \mathrm{N}$ all

297 included timing of grazing, season advancement, and year, or an interaction between timing of 298 grazing or year, and sampling date (Table 1). Intertidal and soil pore $\mathrm{NO}_{3}{ }^{-}-\mathrm{N}$ increased $139 \%$ and 
$119 \%$ in the early grazing treatment compared to typical grazing treatment, while cumulative

300 resin-adsorbed $\mathrm{NO}_{3}^{-}-\mathrm{N}$ decreased by $17 \%$ in late grazing treatment (Figs. 2-4, Table 2). Intertidal

301 resins also had $51 \%$ more $\mathrm{NO}_{3}{ }^{-}-\mathrm{N}$ in no-grazing treatment than typical grazing plots in the last

302 year of the experiment, but had $21 \%$ less $\mathrm{NO}_{3}^{-}-\mathrm{N}$ in the same plots the previous year (Figs. $3 \mathrm{C}$ -

303 D, Table 2). While season advancement was found in all the top models, it was not significant

304 (Supplemental Table S1).

Experimental treatments had no measurable effect on net $\mathrm{N}_{\min }$ rates in year 3. The top models for both net $\mathrm{N}_{\min } \mathrm{NH}_{4}{ }^{+}-\mathrm{N}$ and $\mathrm{NO}_{3}{ }^{-}-\mathrm{N}$ either included just season advancement or the null

307 model (Table 1). In general, the advanced growing season decreased $\mathrm{N}_{\text {min }}$ rates for $\mathrm{NH}_{4}{ }^{+}-\mathrm{N}$ and

$308 \mathrm{NO}^{-}-\mathrm{N}$ by $176 \%$ and $8 \%$, respectively; however, these effects were not significant

309 (Supplemental Table S1). Across all plots, mean net $\mathrm{N}_{\min }$ rates were $0.10 \pm 0.24 \mu \mathrm{g} \mathrm{NH}{ }_{4}^{+}-\mathrm{Ng}^{-}$

310 dry soil ${ }^{-1} \mathrm{~d}^{-1}$ and $0.22 \pm 0.07 \mu \mathrm{g} \mathrm{NO}^{-}-\mathrm{N}$ g-dry soil ${ }^{-1} \mathrm{~d}^{-1}$, or a total of $0.31 \pm 0.25 \mu \mathrm{g}$ inorganic $\mathrm{N}$ 311 g-dry soil ${ }^{-1} \mathrm{~d}^{-1}$.

312 Amino acids increased by $7 \%$ in the early grazing treatment compared to the typical

313 grazing treatment, with peaks in availability observed early in the growing season (Figs. 4G-I).

314 The top model for soil pore amino acid concentrations included timing of grazing and an

315 interaction between year and sampling date, while the second-ranked model with $\Delta$ AIC $<2$ also

316 included season advancement (Table 1). While season advancement was included in the second317 ranked model, it was not significant (Supplemental Table S1).

\section{DISCUSSION}

Our experimental results suggest that the timing of migratory goose grazing (i.e. goose arrival date) has a greater impact on soil $\mathrm{N}$ availability than advancement of the growing season 
322 in this N-limited coastal ecosystem. Early goose grazing had the greatest measurable effect on

323 soil $\mathrm{N}$ by increasing both inorganic and organic soil N pools. Season advancement also increased

324 soil $\mathrm{NH}_{4}{ }^{+}-\mathrm{N}$ availability, but compared to early grazing only had a limited effect on soil $\mathrm{N}$ pools,

325 despite a similar three-week shift in timing (Figure 5). Furthermore, there was no synergistic

326 interaction between timing of goose arrival and timing of spring advancement on soil $\mathrm{N}$

327 availability. Our findings suggest that in coastal western Alaska, where migratory geese are

328 arriving earlier into a phenologically advanced system, soil $\mathrm{N}$ availability will increase. Larger

329 soil $\mathrm{N}$ pools are important for plant nutrient availability, and even short-term impacts on soil $\mathrm{N}$

330 pools can have lasting effects on forage quality (Ruess and others 2019), or alter plant

331 community composition and productivity (Ruess and others 1997; Boyer and Zedler 1999).

332 These shifts in $\mathrm{N}$ may facilitate shifts from graminoid to shrub-dominant vegetation, resulting in

333 a reduction of Carex grazing lawns and goose forage resources (Myers-Smith and others 2011;

334 Carlson and others 2018). Finally, increased $\mathrm{N}$ availability can also result in the greater

335 likelihood of N leaching and potential loss (Jonasson and others 1999).

Soil inorganic $N$ response to timing of grazing treatments

Our findings support hypothesis (H1) that timing of grazing can affect inorganic soil $\mathrm{N}$

339 pools $\left(\mathrm{NH}_{4}{ }^{+}-\mathrm{N}, \mathrm{NO}_{3}{ }^{-}-\mathrm{N}\right)$, and early grazing had the greatest impact (Figure 5). More specifically, 340 early grazing increased resin-adsorbed and soil pore $\mathrm{NH}_{4}{ }^{+}-\mathrm{N}$ availability, which suggests the 341 long-term and short-term influence of this treatment on the different extractable pools. Late 342 grazing also influenced soil $\mathrm{N}$, primarily by reducing intertidal resin-adsorbed $\mathrm{NH}_{4}{ }^{+}-\mathrm{N}$ but not 343 soil pore $\mathrm{NH}_{4}{ }^{+}-\mathrm{N}$ (Table 2), which suggests that the draw down may have taken time (up to three 344 weeks for intertidal resins) for effects to accumulate. By delaying peak $\mathrm{NH}_{4}{ }^{+}-\mathrm{N}$ availability and 
storing $\mathrm{N}$ in plant tissues, late grazing retains $\mathrm{N}$ in the system and returns it slowly through decomposition and microbial turnover, reducing the potential for $\mathrm{N}$ leaching and loss.

Similar to soil $\mathrm{NH}_{4}{ }^{+}-\mathrm{N}$, our findings supported hypothesis (H1) that the timing of grazing also affected $\mathrm{NO}_{3}{ }^{-}-\mathrm{N}$ pools. Changes in pool sizes of $\mathrm{NH}_{4}{ }^{+}-\mathrm{N}$ with both early and late grazing resulted in similar relative changes in $\mathrm{NO}_{3}{ }^{-}-\mathrm{N}$ with the same treatment. However, overall $\mathrm{NO}_{3}{ }^{-}-\mathrm{N}$ concentrations observed across all treatments were 10 times lower than $\mathrm{NH}_{4}{ }^{+}-\mathrm{N}$. We offer four potential mechanisms for this pattern. First, $\mathrm{NO}_{3}{ }^{-}-\mathrm{N}$ is highly mobile in the soil and easily lost through leaching or uptake by plants (Miller and Cramer 2005). Second, saturated soils and low $\mathrm{O}_{2}$ conditions can limit rates of aerobic nitrification (White and Reddy 2003). Third, the anaerobic microbial dissimilatory nitrate reduction to ammonium pathway, a process that converts $\mathrm{NO}_{3}{ }^{-}-\mathrm{N}$ back into $\mathrm{NH}_{4}{ }^{+}-\mathrm{N}$ and occurs in highly reducing environments or flooded soils, may have suppressed $\mathrm{NO}_{3}{ }^{-}-\mathrm{N}$ accumulation (Giblin and others 2013). Finally, it is also possible that $\mathrm{NO}_{3}^{-}-\mathrm{N}$ produced in the soil can be denitrified (Tiedje 1988); however, concurrent measurements in our experimental plots found no significant $\mathrm{N}_{2} \mathrm{O}$ gaseous efflux from our ecosystem (Kelsey and others 2018), suggesting that this is an unlikely pathway.

\section{Soil inorganic $N$ response to season advancement}

Our results support hypothesis (H2) that, by stimulating microbial activity through warmer early season conditions, season advancement increased soil $\mathrm{NH}_{4}{ }^{+}-\mathrm{N}$ pools in excess of any increased plant uptake. Similar to other studies investigating season advancement (Borner and others 2008; Buckeridge and others 2010; Rogers and others 2011), we found a moderate effect of an advanced growing season on soil $\mathrm{NH}_{4}{ }^{+}-\mathrm{N}$. Season advancement also increased soil respiration in our experimental plots (Leffler and others 2019), which suggests that higher rates 
368 of microbial $\mathrm{N}$ cycling contributed to $\mathrm{N}$ pools. Despite having a similar shift in timing of grazing

369 (+3 weeks), this increase was less than the effect of early grazing, which had a four-fold increase

370 in soil pore $\mathrm{NH}_{4}{ }^{+}-\mathrm{N}$ (Table 2), and highlights the importance of earlier migratory arrival at our

371 site. While an advanced growing season increased $\mathrm{NH}_{4}{ }^{+}-\mathrm{N}$, it did not result in a significant

372 increase in $\mathrm{NO}_{3}{ }^{-}-\mathrm{N}$ pools, likely due to the anaerobic suppression of nitrification in saturated

373 soils earlier in the season.

\section{$N$ mineralization response to treatments}

376
We found that $\mathrm{N}_{\min }$ had no measurable response to an advanced season or timing of grazing treatments and was highly variable among plots, which refutes hypotheses $(\mathrm{H} 1 \& \mathrm{H} 2)$ that earlier grazing and an advanced growing season stimulated net $\mathrm{N}$ mobilization. Others have found that $\mathrm{N}_{\min }$ rates were not affected by vegetation clipping treatments in Carex grazing lawns at our site (Person and Ruess 2003) or by goose grazing in the Hudson Bay (Wilson and Jefferies 1996). Studies reporting increases in $\mathrm{N}_{\min }$ from experimental warming had soil temperature increases of $1-3{ }^{\circ} \mathrm{C}$ (e.g. DeMarco and others 2011), suggesting that perhaps our season advancement treatments $\left(0.6\right.$ to $1.0{ }^{\circ} \mathrm{C}$ at $10 \mathrm{~cm}$ belowground only for the first half of the season) were insufficient to increase season-long rates of $\mathrm{N}_{\min }$ and production. The lack of an $\mathrm{N}_{\min }$ response suggests that the observed changes in $\mathrm{N}$ pools from timing of grazing and season advancement were likely driven by plant uptake or microbial immobilization.

\section{Soil organic $N$ pool response to treatments}

Our findings support our hypothesis (H1) that early grazing increases organic N (amino acid) concentrations (Figs. 2G-H). Early peaks in amino acids were observed in all treatments 
391 and may have resulted from the post-melt release of organic $\mathrm{N}$ from the lysing of root and

392 microbial cells during freeze/thaw events in the fall and early spring (Grogan and others 2004).

393 The rapid decline in amino acid concentrations early season coincided with the uptake of

394 available $\mathrm{N}$ by roots for plant growth, as suggested by others in high latitude systems (Weintraub 395 and Schimel 2005; Edwards and others 2006), and likely occurred to a lesser degree in the early 396 grazing treatment due to reduced plant growth (Choi and others 2019). Because microlysimeters

397 measured labile inorganic and organic N available in soil pore water (Darrouzet-Nardi and

398 Weintraub 2014), the observed season-long draw down of the organic $\mathrm{N}$ pool suggests that plants

399 and microbes are utilizing the most easily available limiting resources (Hobbie and Hobbie 2012)

400 (Figs. 2G-I).

401

402

Npathways

We propose that reduced plant uptake was the primary mechanism driving the increase in 404 available soil $\mathrm{N}$ in the early grazing treatments. Although grazing has the potential to stimulate 405 graminoid productivity through compensatory growth (Grogan and Zamin 2018), in our 406 treatments early grazing reduced above- and belowground biomass by $52 \%$ and $55 \%$, 407 respectively, while late grazing increased inflorescences and dead biomass by 515\% and 569\%, 408 respectively (Choi and others 2019), compared to typical grazing plots (Figure 5). These grazing 409 effects had lasting legacy effects on plant productivity in subsequent seasons (Choi and others 410 2019), which corresponded with changes in soil $\mathrm{N}$ availability by the end of our three year 411 experiment.

412 It is possible that other mechanisms contributed to the observed increases in soil $\mathrm{N}$ 413 availability. In northern latitudes where geese are the dominant herbivores, feces are thought to 
414 be important sources of soil N (Bazely and Jefferies 1985). Research conducted in another Arctic

415 coastal system detected amino acid signatures of goose feces in the soil profile (Henry and

416 Jefferies 2002), and plant foliar $\delta^{15} \mathrm{~N}$ from our early grazing treatments had enriched $\delta^{15} \mathrm{~N}$ values

$417(3.3 \%)$ that more closely matched the values of goose feces $(3.7 \%)$, as opposed to late and no-

418 grazing treatments $(2.7 \%$ and $2.1 \%$, respectively) (Beard and Choi 2017). Because of the non-

419 mycorrhizal nature of graminoids (Welker and others 2003; Craine and others 2009), changes in

420 leaf $\delta^{15} \mathrm{~N}$ of Carex species are often due to shifts in $\mathrm{N}$ sources, such as herbivore $\mathrm{N}$ inputs

421 (Sjögersten and others 2010), and the observed changes are likely indicative of substantial $\mathrm{N}$

422 recycling between geese and plants.

Although it is likely that geese are important sources of $\mathrm{N}$ for plants, the effect of goose

424 feces on $\mathrm{N}$ pool sizes remains unclear. An experiment at our site that manipulated goose fecal 425 densities on Carex grazing lawns by creating plots with double, ambient, and no feces found no 426 changes in inorganic or organic soil $\mathrm{N}$ availability using the same $\mathrm{N}$ collection methods used in 427 the present study (Beard and Choi 2017). Further, changes in fecal density did not change Carex 428 biomass or forage quality (Beard and Choi 2017). Observations of goose feces at our site suggest 429 that pellets often dry up and are not incorporated into the soil through trampling, while frequent 430 flooding and high tide events redistributed or removed $85-90 \%$ of feces (Beard and Choi 2017).

431 Because soluble $\mathrm{N}$ rapidly declines in goose feces after deposition (Bazely and Jefferies 1985), 432 we speculate that a portion of $\mathrm{N}$ volatilizes into the atmosphere. While we believe that goose 433 feces play a role in soil $\mathrm{N}$ availability, the magnitude of its influence on soil $\mathrm{N}$ pools at our site 434 still warrants further investigation. 
While both early grazing and an advanced growing season, in general, increase $\mathrm{N}$ availability in soil pools, there were no observed interactions between timing of grazing and timing of season treatments (H3). It is possible that the compensatory growth response of Carex

440 grazing lawns to early goose herbivory, in particular because of the increased soil $\mathrm{N}$ availability

441 (Grogan and Zamin 2018), may have dampened the increase in $\mathrm{N}$ availability from early grazing 442 and the advanced season (Choi and others 2019). Alternatively, while warmer temperatures and 443 reduced leaf shading seemed to increase $\mathrm{N}$ mobilization, these conditions also likely lowered soil

444 water content, thereby limiting rates of microbial decomposition and accumulation of inorganic 445 N pools (Skopp and others 1990). Because both earlier goose arrival and advancing green-up are 446 occurring at our site, our findings suggest that there will be additive, but not synergistic, 447 increases in soil $\mathrm{N}$ availability.

Soil $N$ collections and limitations

The different methods of $\mathrm{N}$ measurements we employed captured different aspects of the 451 available soil $\mathrm{N}$ pools. We used microlysimeters to measure the labile soil pore $\mathrm{N}$ pools at 452 biweekly intervals and this $\mathrm{N}$ was more sensitive to short-term differences in availability, 453 compared to the less frequently collected ion-exchange resins that accumulated changes in soil 454 adsorbed $\mathrm{N}$ over time. Of the resin measurements, it is not surprising that intertidal resins 455 detected a stronger response to grazing treatments given that they were designed to reduce 456 interference from tidal inundation. Because $\mathrm{N}$ availability in northern coastal systems has high 457 temporal and spatial variability (McLaren and others 2017; Darrouzet-Nardi and others 2019), 458 our relatively high frequency of measurements and multiple approaches helped improve our 459 understanding of soil $\mathrm{N}$ fluctuations and availability across the growing season. 
CONCLUSIONS

Climate-driven advances in spring green-up and goose arrival are occurring in the Y-K

463 Delta. While both earlier growing seasons and earlier goose arrival result in increased soil $\mathrm{NH}_{4}^{+}-$

$464 \mathrm{~N}$ availability, the effect of season advancement was less than that of early goose grazing, even

465 though both treatments were earlier by about three weeks. Our findings suggest that climate466 driven changes in the timing of migratory goose arrival has important top-down control on the

467 timing and availability of $\mathrm{N}$, which is a critical limiting resource in this northern coastal wetland.

468 While larger soil $\mathrm{N}$ pools are important for plant nutrient availability, they can also result in a

469 greater likelihood of leaching and potential loss. If these earlier migratory patterns persist,

470 greater soil $\mathrm{N}$ availability is also likely to result in altered vegetation community composition

471 and potential loss of goose forage resources.

\section{ACKNOWLEDGEMENTS}

474 Work was funded by National Science Foundation awards ARC-1304523 and ARC-1304879, 475 and by the Utah Agricultural Experiment Station, Utah State University, and approved as journal 476 paper \#9222. R. Choi received support from National Science Foundation award DGE-1633756 477 and J. Leffler from the South Dakota Agricultural Experiment Station. We thank D. Douglas 478 (USGS) for data on season advancement; N. Dickenson for laboratory resources; S. Durham for 479 statistical advice; K. Foley for field soil measurements; H. Braithwaite, L. Carlson, T. 480 DeMasters, J. Ferguson, R. Hicks, M. Holdrege, K. Lynöe, and S. Walden for field assistance; A. 481 Albee, K. Curtis, and S. Sprouse for laboratory assistance; M. Irinaga, L. Gullingsrud, and L. 482 McFadden at CH2M Hill Polar Services for logistical assistance; Yukon Delta National Wildlife 
Refuge staff; and the people of Chevak, AK. Permits obtained for this work include - ADF\&G permit: 16-23; USFWS NWR special use permit: FF07RYKD0-14-06; USFWS Migratory Bird permit: MB28352B-0; USU IACUC: 2004. Data are published online at the NSF Arctic Data Center (doi: 10.18739/A22274). Any use of trade, firm, or product names is for descriptive purposes only and does not imply endorsement by the US Government.

Conflict of Interest: The authors declare that they have no conflict of interest.

\section{LITERATURE CITED}

Bai E, Li S, Xu W, Li W, Dai W, Jiang P. 2013. A meta-analysis of experimental warming effects on terrestrial nitrogen pools and dynamics. New Phytol 199:441-51.

Bardgett RD, Manning P, Morriën E, De Vries FT. 2013. Hierarchical responses of plant-soil interactions to climate change: consequences for the global carbon cycle. J Ecol 101:33443.

Bazely DR, Jefferies RL. 1985. Goose faeces: a source of nitrogen for plant growth in a grazed salt marsh. J Appl Ecol 22:693-703.

Bazely DR, Jefferies RL. 1989. Lesser snow geese and the nitrogen economy of a grazed salt marsh. J Ecol 77:24-34.

Beard KH, Choi RT. 2017. Data from: Asynchrony in the timing of goose-vegetation interactions: implications for biogeochemical cycling in wet sedge tundra Tutakoke River, Yukon Delta NWR, Alaska, 2014-2016.

Beard KH, Choi RT, Leffler AJ, Carlson LG, Kelsey KC, Schmutz JA, Welker JM. 2019a. Migratory goose arrival time plays a larger role in influencing forage quality than advancing springs in an Arctic coastal wetland. PLoS One 14:e0213037.

Beard KH, Kelsey KC, Leffler AJ, Welker JM. 2019b. The missing angle: ecosystem consequences of phenological mismatch. Trends Ecol Evol 34:885-8.

Belay-Tedla A, Zhou X, Su B, Wan S, Luo Y. 2009. Labile, recalcitrant, and microbial carbon and nitrogen pools of a tallgrass prairie soil in the US Great Plains subjected to experimental warming and clipping. Soil Biol Biochem 41:110-6.

Blankinship JC, Hart SC. 2012. Consequences of manipulated snow cover on soil gaseous emission and $\mathrm{N}$ retention in the growing season: a meta-analysis. Ecosphere 3:1-20.

Boelman NT, Krause JS, Sweet SK, Chmura HE, Perez JH, Gough L, Wingfield JC. 2017. 
Extreme spring conditions in the Arctic delay spring phenology of long-distance migratory songbirds. Oecologia 185:1-12.

Borner AP, Kielland K, Walker MD. 2008. Effects of simulated climate change on plant phenology and nitrogen mineralization in Alaskan Arctic tundra. Arctic, Antarct Alp Res 40:27-38.

Boyer KE, Zedler JB. 1999. Nitrogen addition could shift plant community composition in a restored California salt marsh. Restor Ecol 7:74-85.

Brook RW, Leafloor JO, Abraham KF, Douglas DC. 2015. Density dependence and phenological mismatch: consequences for growth and survival of sub-arctic nesting Canada Geese. Avian Conserv Ecol 10:1.

Buckeridge KM, Cen Y-P, Layzell DB, Grogan P. 2010. Soil biogeochemistry during the early spring in low arctic mesic tundra and the impacts of deepened snow and enhanced nitrogen availability. Biogeochemistry 99:127-41.

Buckeridge KM, Grogan P. 2010. Deepened snow increases late thaw biogeochemical pulses in mesic low arctic tundra. Biogeochemistry 101:105-21.

Burnham KP, Anderson DR, Huyvaert KP. 2011. AIC model selection and multimodel inference in behavioral ecology: some background, observations, and comparisons. Behav Ecol Sociobiol 65:23-35.

Carlson LG, Beard KH, Adler PB. 2018. Direct effects of warming increase woody plant abundance in a subarctic wetland. Ecol Evol:1-12.

Choi RT, Beard KH, Leffler AJ, Kelsey KC, Schmutz JA, Welker JM. 2019. Phenological mismatch between season advancement and migration timing alters Arctic plant traits. Cornelissen H, editor. J Ecol 107:2503-18.

Clausen KK, Clausen P. 2013. Earlier Arctic springs cause phenological mismatch in longdistance migrants. Oecologia 173:1101-12.

Cohen JM, Lajeunesse MJ, Rohr JR. 2018. A global synthesis of animal phenological responses to climate change. Nat Clim Chang 8:224-8.

Craine JM, Elmore AJ, Aidar MPM, Bustamante M, Dawson TE, Hobbie EA, Kahmen A, MacK MC, McLauchlan KK, Michelsen A, Nardoto GB, Pardo LH, Peñuelas J, Reich PB, Schuur EAG, Stock WD, Templer PH, Virginia RA, Welker JM, Wright IJ. 2009. Global patterns of foliar nitrogen isotopes and their relationships with climate, mycorrhizal fungi, foliar nutrient concentrations, and nitrogen availability. New Phytol 183:980-92.

Darrouzet-Nardi A, Steltzer H, Sullivan PF, Segal A, Koltz AM, Livensperger C, Schimel JP, Weintraub MN. 2019. Limited effects of early snowmelt on plants, decomposers, and soil nutrients in Arctic tundra soils. Ecol Evol 9:1820-44.

Darrouzet-Nardi A, Weintraub MN. 2014. Evidence for spatially inaccessible labile N from a comparison of soil core extractions and soil pore water lysimetry. Soil Biol Biochem 73:2232 . 
DeMarco J, Mack MC, Bret-Harte MS. 2011. The effects of snow, soil microenvironment, and soil organic matter quality on $\mathrm{N}$ availability in three Alaskan Arctic plant communities. Ecosystems 14:804-17.

Doane TA, Horwáth WR. 2003. Spectrophotometric determination of nitrate with a single reagent. Anal Lett 36:2713-22.

Doiron M, Gauthier G, Levesque E. 2015. Trophic mismatch and its effects on the growth of young in an Arctic herbivore. Glob Chang Biol 21:4364-76.

Edwards KA, McCulloch J, Kershaw GP, Jefferies RL. 2006. Soil microbial and nutrient dynamics in a wet Arctic sedge meadow in late winter and early spring. Soil Biol Biochem 38:2843-51.

Fischer JB, Stehn RA, Walters G. 2008. Nest population size and potential production of geese and spectacled eiders on the Yukon-Kuskokwim Delta, Alaska, 2008. U.S. Fish and Wildlife Service, Migratory Bird Management, Anchorage, AK

Fischer JB, Williams AR, Stehn RA. 2017. Nest population size and potential production of geese and spectacled eiders on the Yukon-Kuskokwim Delta, Alaska, 1985-2016. U.S. Fish and Wildlife Service, Migratory Bird Management, Anchorage, AK

Giblin AE, Tobias CR, Song B, Weston N, Banta GT, Rivera-Monroy VH. 2013. The importance of dissimilatory nitrate reduction to ammonium (DNRA) in the nitrogen cycle of coastal ecosystems. Oceanography 26:124-31.

Grogan P, Michelsen A, Ambus P, Jonasson S. 2004. Freeze-thaw regime effects on carbon and nitrogen dynamics in sub-arctic heath tundra mesocosms. Soil Biol Biochem 36:641-54.

Grogan P, Zamin TJ. 2018. Growth responses of the common arctic graminoid Eriophorum vaginatum to simulated grazing are independent of soil nitrogen availability. Oecologia 186:151-62.

Heberling JM, McDonough MacKenzie C, Fridley JD, Kalisz S, Primack RB. 2019. Phenological mismatch with trees reduces wildflower carbon budgets. Ecol Lett 22:616-23.

Henry HAL, Jefferies RL. 2002. Free amino acid, ammonium and nitrate concentrations in soil solutions of a grazed coastal marsh in relation to plant growth. Plant, Cell Environ 25:66575 .

Henry HAL, Jefferies RL. 2003. Plant amino acid uptake, soluble N turnover and microbial N capture in soils of a grazed Arctic salt marsh. J Ecol 91:627-36.

Hobbie JE, Hobbie EA. 2012. Amino acid cycling in plankton and soil microbes studied with radioisotopes: measured amino acids in soil do not reflect bioavailability. Biogeochemistry 107:339-60.

Jonasson S, Michelsen A, Schmidt IK. 1999. Coupling of nutrient cycling and carbon dynamics in the Arctic, integration of soil microbial and plant processes. Appl Soil Ecol 11:135-46.

Jones DL, Owen AG, Farrar JF. 2002. Simple method to enable the high resolution determination of total free amino acids in soil solutions and soil extracts. Soil Biol Biochem 
34:1893-902.

592

593

594

595

596

597

598

599

600

601

602

603

604

605

606

607

608

609

610

611

612

613

614

615

616

617

618

619

620

621

622

623

624

625

626

627

628
Jorgenson MT. 2000. Hierarchical organization of ecosystems at multiple spatial scales on the Yukon-Kuskokwim Delta, Alaska, U.S.A. Arctic, Antarct Alp Res 32:221-39.

Jorgenson T, Ely C. 2001. Topography and flooding of coastal ecosystems on the YukonKuskokwim Delta, Alaska: implications for sea-level rise. J Coast Res 17:124-36.

Kelsey KC, Leffler AJ, Beard KH, Choi RT, Schmutz JA, Welker JM. 2018. Phenological mismatch in coastal western Alaska may increase summer season greenhouse gas uptake. Environ Res Lett 13:044032.

Kölzsch A, Bauer S, de Boer R, Griffin L, Cabot D, Exo KM, van der Jeugd HP, Nolet BA. 2015. Forecasting spring from afar? Timing of migration and predictability of phenology along different migration routes of an avian herbivore. J Anim Ecol 84:272-83.

Lameris TK, Scholten I, Bauer S, Cobben MMP, Ens BJ, Nolet BA. 2017. Potential for an Arctic-breeding migratory bird to adjust spring migration phenology to Arctic amplification. Glob Chang Biol 23:4058-67.

Leffler AJ, Beard KH, Kelsey KC, Choi RT, Schmutz JA, Welker JM. 2019. Delayed herbivory by migratory geese increases summer-long $\mathrm{CO} 2$ uptake in coastal western Alaska. Glob Chang Biol 25:277-89.

Lin D, Xia J, Wan S. 2010. Climate warming and biomass accumulation of terrestrial plants: a meta-analysis. New Phytol 188:187-98.

Martinsen V, Mulder J, Austrheim G, Hessen DO, Mysterud A. 2012. Effects of sheep grazing on availability and leaching of soil nitrogen in low-alpine grasslands. Arctic, Antarct Alp Res 44:67-82.

Mayor SJ, Guralnick RP, Tingley MW, Otegui J, Withey JC, Elmendorf SC, Andrew ME, Leyk S, Pearse IS, Schneider DC. 2017. Increasing phenological asynchrony between spring green-up and arrival of migratory birds. Sci Rep 7:1902.

McBride MB. 1989. Surface chemistry of soil minerals. Miner Soil Environ 2:35-87.

McLaren JR, Darrouzet-Nardi A, Weintraub MN, Gough L. 2017. Seasonal patterns of soil nitrogen availability in moist acidic tundra. Arct Sci 4:AS-2017-0014.

Miller-Rushing AJ, Høye TT, Inouye DW, Post E. 2010. The effects of phenological mismatches on demography. Philos Trans R Soc Lond B Biol Sci 365:3177-86.

Miller AJ, Cramer MD. 2005. Root nitrogen acquisition and assimilation. Plant Soil 274:1-36.

Myers-Smith IH, Forbes BC, Wilmking M, Hallinger M, Lantz T, Blok D, Tape KD, MaciasFauria M, Sass-Klaassen U, Lévesque E, Boudreau S, Ropars P, Hermanutz L, Trant A, Collier LS, Weijers S, Rozema J, Rayback S a, Schmidt NM, Schaepman-Strub G, Wipf S, Rixen C, Ménard CB, Venn S, Goetz S, Andreu-Hayles L, Elmendorf S, Ravolainen V, Welker J, Grogan P, Epstein HE, Hik DS. 2011. Shrub expansion in tundra ecosystems: dynamics, impacts and research priorities. Environ Res Lett 6:045509.

Natali SM, Schuur EAG, Rubin RL. 2012. Increased plant productivity in Alaskan tundra as a 
result of experimental warming of soil and permafrost. J Ecol 100:488-98.

630

631

632

633

634

635

636

637

638

639

640

641

642

643

644

645

646

647

648

649

650

651

652

653

654

655

656

657

658

659

660

661

662

663

664

665

666
Person BT, Herzog MP, Ruess RW, Sedinger JS, Anthony RM, Babcock CA. 2003. Feedback dynamics of grazing lawns: coupling vegetation change with animal growth. Oecologia 135:583-92.

Person BT, Ruess RW. 2003. Stability of a subarctic saltmarsh: plant community resistance to tidal inundation. Ecoscience 10:351-60.

Pinheiro J, Bates D, DebRoy S, Sarkar D, R Core Team. 2017. nmle: linear and nonlinear mixed effects models. R Packag version 31- $131 \mathrm{https//CRANR-project.org/package=nlme.}$

Qian P, Schoenau JJ. 1995. Assessing nitrogen mineralization from soil organic matter using anion exchange membranes. Fertil Res 40:143-8.

Renner SS, Zohner CM. 2018. Climate change and phenological mismatch in trophic interactions among plants, insects, and vertebrates. Annu Rev Ecol Evol Syst 49:165-82.

Rhine ED, Mulvaney RL, Pratt EJ, Sims GK. 1998. Improving the Berthelot reaction for determining ammonium in soil extracts and water. Soil Sci Soc Am J 62:473-80.

Robertson GP, Wedin D, Groffman PM, Blair JM, Holland EA, Nadelhoffer KJ, Harris D. 1999. Soil carbon and nitrogen availability: nitrogen mineralization, nitrification, and soil respiration potentials. In: Robertson GP, Coleman DC, Bledsoe CS, Sollins P, editors. Standard Soil Methods for Long-Term Ecological Research. New York, NY: Oxford University Press. pp 258-71.

Rogers MC, Sullivan PF, Welker JM. 2011. Evidence of nonlinearity in the response of net ecosystem CO2 exchange to increasing levels of winter snow depth in the High Arctic of northwest Greenland. Arctic, Antarct Alp Res 43:95-106.

Ross M V., Alisauskas RT, Douglas DC, Kellett DK. 2017. Decadal declines in avian herbivore reproduction: density-dependent nutrition and phenological mismatch in the Arctic. Ecology 98:1869-83.

Ruess RW, McFarland JW, Person B, Sedinger JS. 2019. Geese mediate vegetation state changes with parallel effects on $\mathrm{N}$ cycling that leave nutritional legacies for offspring. Ecosphere 10.

Ruess RW, Uliassi DD, Mulder CPH, Person BT. 1997. Growth responses of Carex ramenskii to defoliation, salinity, and nitrogen availability: implications for geese-ecosystem dynamics in western Alaska. Ecoscience 4:170-8.

Schaeffer SM, Sharp E, Schimel JP, Welker JM. 2013. Soil-plant N processes in a High Arctic ecosystem, NW Greenland are altered by long-term experimental warming and higher rainfall. Glob Chang Biol 19:3529-39.

Schimel JP, Kielland K, Chapin FS. 1996. Nutrient availability and uptake by tundra plants. In: Reynolds JF, Tenhunen JD, editors. Landscape Function and Disturbance in Arctic Tundra. Ecological Studies (Analysis and Synthesis), vol 120. Springer Berlin Heidelberg. pp 20321.

Sedinger JS, Herzog MP, Person BT, Kirk MT, Obritchkewitch T, Martin PP, Stickney AA. 
2001. Large-scale variation in growth of Black Brant goslings related to food availability. Auk 118:1088-95.

Sedinger JS, Raveling DG. 1984. Dietary selectivity in relation to availability and quality of food for goslings of Cackling Geese. Auk 101:295-306.

Sedinger JS, Raveling DG. 1986. Timing of nesting by Canada geese in relation to the phenology and availability of their food plants. J Anim Ecol 55:1083-102.

Sistla SA, Asao S, Schimel JP. 2012. Detecting microbial N-limitation in tussock tundra soil: Implications for Arctic soil organic carbon cycling. Soil Biol Biochem 55:78-84.

Sistla SA, Schimel JP. 2013. Seasonal patterns of microbial extracellular enzyme activities in an arctic tundra soil: Identifying direct and indirect effects of long-term summer warming. Soil Biol Biochem 66:119-29.

Sjögersten S, Kuijper DPJ, van der Wal R, Loonen MJJE, Huiskes AHL, Woodin SJ. 2010. Nitrogen transfer between herbivores and their forage species. Polar Biol 33:1195-203.

Skopp J, Jawson MD, Doran JW. 1990. Steady-state aerobic microbial activity as a function of soil water content. Soil Sci Soc Am J 54:1619.

Tiedje JM. 1988. Ecology of denitrification and dissimilatory nitrate reduction to ammonium. In: Zehnder AJB, editor. Environmental Microbiology of Anaerobes. John Wiley \& Sons, N.Y. pp 179-244.

Uher-Koch BD, Schmutz JA, Wilson HM, Anthony RM, Day TL, Fondell TF, Person BT, Sedinger JS. 2019. Ecosystem-scale loss of grazing habitat impacted by abundance of dominant herbivores. Ecosphere 10:e02767.

Weintraub MN, Schimel JP. 2005. The seasonal dynamics of amino acids and other nutrients in Alaskan Arctic tundra soils. Biogeochemistry 73:359-80.

Welker JM, Jonsdottir IS, Fahnestock JT. 2003. Leaf isotopic (d13C and d15N) and nitrogen contents of Carex plants along the Eurasian Coastal Arctic: Results from the Northeast Passage expedition. Polar Biol 27:29-37.

White JR, Reddy KR. 2003. Nitrification and denitrification rates of Everglades wetland soils along a phosphorus-impacted gradient. J Environ Qual 32:2436.

Wilson DJ, Jefferies RL. 1996. Nitrogen mineralization, plant growth and goose herbivory in an Arctic coastal ecosystem. J Ecol 84:841-51.

Zacheis A, Ruess R, Hupp J. 2002. Nitrogen dynamics in an Alaskan salt marsh following spring use by geese. Oecologia 130:600-8. 


\section{TABLES}

Table 1.

\begin{tabular}{|c|c|c|c|c|c|c|}
\hline Model & logLik & $\mathrm{AIC}$ & $\Delta$ LogLik & $\triangle \mathrm{AIC}$ & df & weight \\
\hline \multicolumn{7}{|l|}{ Cumulative resin $\mathrm{NH}_{4}{ }^{+}-\mathrm{N}$} \\
\hline Year + Grazing*Date & -1155.1 & 2338.3 & 111.2 & 0.0 & 14 & 0.564 \\
\hline Year + Grazing $*$ Date + Season & -1154.4 & 2338.8 & 112.0 & 0.5 & 15 & 0.434 \\
\hline Year*Date + Grazing & -1162.3 & 2350.6 & 104.0 & 12.3 & 13 & 0.001 \\
\hline Year*Date + Grazing + Season & -1161.6 & 2351.1 & 104.8 & 12.9 & 14 & $<0.001$ \\
\hline \multicolumn{7}{|l|}{ Intertidal resin $\mathrm{NH}_{4}{ }^{+}-\mathrm{N}$} \\
\hline Year + Grazing*Date + Season & -404.7 & 837.5 & 84.6 & 0 & 14 & 0.923 \\
\hline Year + Grazing*Date & -408.2 & 842.5 & 81.1 & 5 & 13 & 0.077 \\
\hline Year*Season + Grazing + Date & -426.0 & 876.1 & 63.3 & 38.6 & 12 & $<0.001$ \\
\hline Year*Grazing + Season + Date & -424.1 & 876.1 & 65.3 & 38.6 & 14 & $<0.001$ \\
\hline \multicolumn{7}{|l|}{ Microlysimeter $\mathrm{NH}_{4}{ }^{+}-\mathrm{N}$} \\
\hline Year*Date + Grazing & -1360.2 & 2746.5 & 24.9 & 0.0 & 13 & 0.323 \\
\hline Year*Date + Grazing + Season & -1359.7 & 2747.4 & 25.5 & 0.9 & 14 & 0.206 \\
\hline Year*Date & -1364.0 & 2748.0 & 21.2 & 1.5 & 10 & 0.152 \\
\hline Year*Date + Season & -1363.5 & 2749.1 & 21.6 & 2.6 & 11 & 0.088 \\
\hline \multicolumn{7}{|l|}{ Cumulative resin $\mathrm{NO}_{3}{ }^{-}-\mathrm{N}$} \\
\hline Year*Date + Grazing & -1239.7 & 2505.3 & 184.6 & 0.0 & 13 & 0.723 \\
\hline Year*Date + Grazing + Season & -1239.7 & 2507.3 & 184.6 & $2.0 *$ & 14 & 0.267 \\
\hline Year*Date & -1247.2 & 2514.5 & 177.0 & 9.2 & 10 & 0.007 \\
\hline Year*Date + Season & -1247.2 & 2516.5 & 177.0 & 11.2 & 11 & 0.003 \\
\hline \multicolumn{7}{|l|}{ Intertidal resin $\mathrm{NO}_{3}{ }^{-}-\mathrm{N}$} \\
\hline Year + Grazing*Date & -390.1 & 806.1 & 56.6 & 0 & 13 & 0.369 \\
\hline Year*Date + Grazing & -392.6 & 807.3 & 54.1 & 1.1 & 11 & 0.211 \\
\hline Year + Grazing $*$ Date + Season & -390.1 & 808.1 & 56.6 & $2.0 *$ & 14 & 0.136 \\
\hline Year*Date + Grazing + Season & -392.6 & 809.2 & 54.1 & 3.1 & 12 & 0.078 \\
\hline \multicolumn{7}{|l|}{ Microlysimeter $\mathrm{NO}_{3}{ }^{-}-\mathrm{N}$} \\
\hline Year*Date & -1498.3 & 3016.6 & 50.2 & 0.0 & 10 & 0.380 \\
\hline Year*Date + Season & -1497.6 & 3017.3 & 50.8 & 0.7 & 11 & 0.270 \\
\hline Year*Date + Grazing & -1495.9 & 3017.9 & 52.5 & 1.3 & 13 & 0.200 \\
\hline Year*Date + Grazing + Season & -1495.3 & 3018.6 & 53.2 & 1.9 & 14 & 0.150 \\
\hline \multicolumn{7}{|l|}{$\mathrm{N}$-mineralization $\mathrm{NH}_{4}^{+}-\mathrm{N}$} \\
\hline Season & -13.6 & 37.3 & 1.6 & 0.0 & 5 & 0.543 \\
\hline Null model & -15.3 & 38.5 & 0.0 & 1.3 & 4 & 0.291 \\
\hline
\end{tabular}


Grazing + Season

Grazing

$\mathrm{N}$-mineralization $\mathrm{NO}_{3}{ }^{-}-\mathrm{N}$

Null model

Season

Grazing

Grazing + Season
$-12.2 \quad 40.4$

$-14.2 \quad 42.4$

3.1

1.0

3.18

5.27

0.114

$-14.2$

\section{7}

$8.7-7.4$

0.0

$\begin{array}{lll}0.0 & 4 & 0.638\end{array}$

$9.6-5.1$

$9.6-3.2$

0.0

1.95

0.242

$\begin{array}{llll}0.9 & 4.2 & 7 & 0.079\end{array}$

$\begin{array}{llll}0.9 & 6.2 & 8 & 0.029\end{array}$

Microlysimeter amino acids

\begin{tabular}{|c|c|c|c|c|c|}
\hline Year*Date + Grazing & -1290.6 & 2607.3 & 99.2 & 0.013 & 0.504 \\
\hline Year*Date + Grazing + Season & -1290.0 & 2608.0 & 99.8 & 0.714 & 0.349 \\
\hline Year*Date & -1295.4 & 2610.8 & 94.4 & 3.510 & 0.086 \\
\hline Year*Date + Season & -1294.8 & 2611.5 & 95.1 & 4.211 & 0.061 \\
\hline
\end{tabular}


Table 2.

\begin{tabular}{|c|c|c|c|c|c|c|c|c|c|}
\hline \multirow[b]{2}{*}{ Effect } & \multicolumn{3}{|c|}{$\begin{array}{c}\text { Cumulative resin } \\
\mathrm{NH}_{4}{ }^{+}-\mathrm{N}\end{array}$} & \multicolumn{3}{|c|}{$\begin{array}{c}\text { Intertidal resin } \\
\mathrm{NH}_{4}{ }^{+}-\mathrm{N}\end{array}$} & \multicolumn{3}{|c|}{$\begin{array}{l}\text { Microlysimeter } \\
\mathrm{NH}_{4}{ }^{+}-\mathrm{N}\end{array}$} \\
\hline & 2014 & 2015 & 2016 & 2014 & 2015 & 2016 & 2014 & 2015 & 2016 \\
\hline Early & $128 \%$ & $44 \%$ & $62 \% *$ & - & $32 \%$ & $21 \% *$ & $112 \%$ & $88 \%$ & $110 \%$ \\
\hline Late & $-28 \%$ & $-32 \%$ & $-26 \%$ & - & $-1 \%$ & $-16 \% *$ & $39 \%$ & $11 \%$ & $1 \%$ \\
\hline None & $-44 \%$ & $-51 \%$ & $-43 \%$ & - & $-57 \%$ & $-48 \%$ & $75 \%$ & $-3 \%$ & $-22 \%$ \\
\hline \multirow[t]{2}{*}{ Advanced } & $5 \%$ & $-7 \%$ & $-15 \%$ & - & $-13 \%$ & $2 \%$ & $29 \%$ & $19 \%$ & $26 \%$ \\
\hline & \multicolumn{3}{|c|}{$\begin{array}{c}\text { Cumulative resin } \\
\mathrm{NO}_{3}-\mathrm{N}\end{array}$} & \multicolumn{3}{|c|}{$\begin{array}{c}\text { Intertidal resin } \\
\mathrm{NO}_{3}-\mathrm{N}\end{array}$} & \multicolumn{3}{|c|}{$\begin{array}{c}\text { Microlysimeter } \\
\mathrm{NO}_{3}-\mathrm{N}\end{array}$} \\
\hline Effect & 2014 & 2015 & 2016 & 2014 & 2015 & 2016 & 2014 & 2015 & 2016 \\
\hline$\overline{\text { Early }}$ & $28 \%$ & $11 \%$ & $-10 \%$ & - & $49 \%$ & $139 \%$ & $55 \%$ & $3 \%$ & $119 \%$ \\
\hline Late & $-28 \%$ & $-28 \%$ & $-17 \%$ & - & $-21 \%$ & $39 \%$ & $33 \%$ & $14 \%$ & $39 \%$ \\
\hline None & $-2 \%$ & $-28 \%$ & $-41 \%$ & - & $-21 \%$ & $51 \% *$ & $8 \%$ & $14 \%$ & $34 \%$ \\
\hline \multirow[t]{2}{*}{ Advanced } & $-17 \%$ & $-4 \%$ & $32 \%$ & - & $-4 \%$ & $9 \%$ & $22 \%$ & $-3 \%$ & $7 \%$ \\
\hline & \multicolumn{3}{|c|}{$\begin{array}{c}\mathrm{N} \text {-mineralization } \\
\mathrm{NH}_{4}^{+}-\mathrm{N}\end{array}$} & \multicolumn{3}{|c|}{$\begin{array}{c}\text { N-mineralization } \\
\mathrm{NO}_{3}-\mathrm{N}\end{array}$} & \multicolumn{3}{|c|}{$\begin{array}{l}\text { Microlysimeter } \\
\text { amino acids }\end{array}$} \\
\hline Effect & 2014 & 2015 & 2016 & 2014 & 2015 & 2016 & 2014 & 2015 & 2016 \\
\hline Early & - & - & $-1706 \%$ & - & - & $161 \%$ & $23 \%$ & $7 \%$ & $7 \%$ \\
\hline Late & - & - & $1387 \%$ & - & - & $113 \%$ & $-28 \%$ & $-9 \%$ & $-4 \%$ \\
\hline None & - & - & $1279 \%$ & - & - & $8 \%$ & $-18 \%$ & $-31 \%$ & $-1 \%$ \\
\hline Advanced & - & - & $-176 \%$ & - & - & $-8 \%$ & $-17 \%$ & $-15 \%$ & $-6 \%$ \\
\hline
\end{tabular}




\section{TABLE LEGENDS}

Table 1. Top four performing models for soil $\mathrm{N}$ response variables based on AIC model selection for experimental treatments over three years (2014-16). Abbreviations: Grazing = timing of goose grazing treatment, Season $=$ season advancement treatment, Date $=$ sampling date. Models with interaction terms imply inclusion of the main effect. Bolding indicate top models with $\Delta \mathrm{AIC}<2$.

Table 2. Mean percent changes by treatment for each year. The reference level was the ambient growing season or typical grazing timing treatment, respectively. Abbreviations: Early = early grazing, Late $=$ late grazing, None $=$ no-grazing, Advanced $=$ advanced growing season treatment. Bolding indicates treatment effect with $\mathrm{p}<0.05 ;\left(^{*}\right)$ indicates sampling date interaction. 


\section{FIGURE LEGENDS}

Figure 1. Conceptual figure of experimental hypotheses $(\mathrm{H} 1, \mathrm{H} 2, \mathrm{H} 3)$ regarding the influence of the timing of goose grazing and the start of the growing season and their interaction on soil $\mathrm{N}$ availability. Arrows indicate hypothesized influence on N pools; blue arrows indicate positive effects and red arrows indicate negative effects. Goose herbivory removes aboveground tissues and hence decreases plant $\mathrm{N}$ uptake, while trampling and fecal deposition increase $\mathrm{N}$ availability; an advanced spring with warmer soil temperatures stimulates earlier plant and microbial growth; the interaction increases $\mathrm{N}$ availability due to increase microbial activity with less aboveground biomass to increase $\mathrm{N}$ uptake. Sub-figures are the hypothesized directional response of treatments on soil $\mathrm{N}$ availability.

Figure 2. Mean cumulative resin $\mathrm{NH}_{4}{ }^{+}-\mathrm{N}$ and $\mathrm{NO}_{3}-\mathrm{N}\left(\mu \mathrm{g} \mathrm{d}^{-1} \mathrm{~cm}^{-2}\right)( \pm 1 \mathrm{SE})$ from experimental timing of grazing and season advancement treatments. Panels A, B, C, and D, E, F represent data collected from 2014, 2015, and 2016, respectively. Dotted lines represent high tide events that flooded plots and in situ resins (Julian dates 2014 (205), 2015 (186), 2016 (186, 210)).

Figure 3. Mean intertidal resin $\mathrm{NH}_{4}{ }^{+}-\mathrm{N}$ and $\mathrm{NO}_{3}-\mathrm{N}\left(\mu \mathrm{g} \mathrm{d}^{-1} \mathrm{~cm}^{-2}\right)$ from experimental timing of grazing and season advancement treatments. Because cumulative resins experienced coastal flooding, intertidal resins collected soil inorganic $\mathrm{N}$ during periods in between monthly tidal inundation to avoid ionic loss of $\mathrm{N}$ from resins in situ. Panels A, B and C, D represent data collected from 2015 and 2016, respectively. Error bars are \pm 1 SE ( $n=6$ replicates).

Figure 4. Mean microlysimeter $\mathrm{NH}_{4}{ }^{+}-\mathrm{N}$ and $\mathrm{NO}_{3}-\mathrm{N}\left(\mu \mathrm{g} \mathrm{L}^{-1}\right)$ and amino acids (AA) $\left(\mu \mathrm{mol} \mathrm{L}{ }^{-1}\right)$ ( $\pm 1 \mathrm{SE}$ ) from soil pore water for treatment plots. Panels A, B, C, and D, E, F, and G, H, I represent data collected from 2014, 2015, and 2016, respectively. Leu* $=$ Leucine equivalent.

Figure 5. Conceptual figure of experimental treatments (timing of grazing and season advancement) on soil $\mathrm{N}$ measurements (cumulative and intertidal resins, and microlysimeter pore water) compared to typical grazing and ambient season treatments after three years. Arrow thickness indicates relative treatment effect size. Blue arrows indicate a positive effect; red arrows indicate a negative effect. Measurements without arrows had no significant measured treatment effect. Depicted above- and belowground vegetation represent actual measurements from early grazing and season advancement treatments, respectively (Choi and others 2019). 
FIGURES

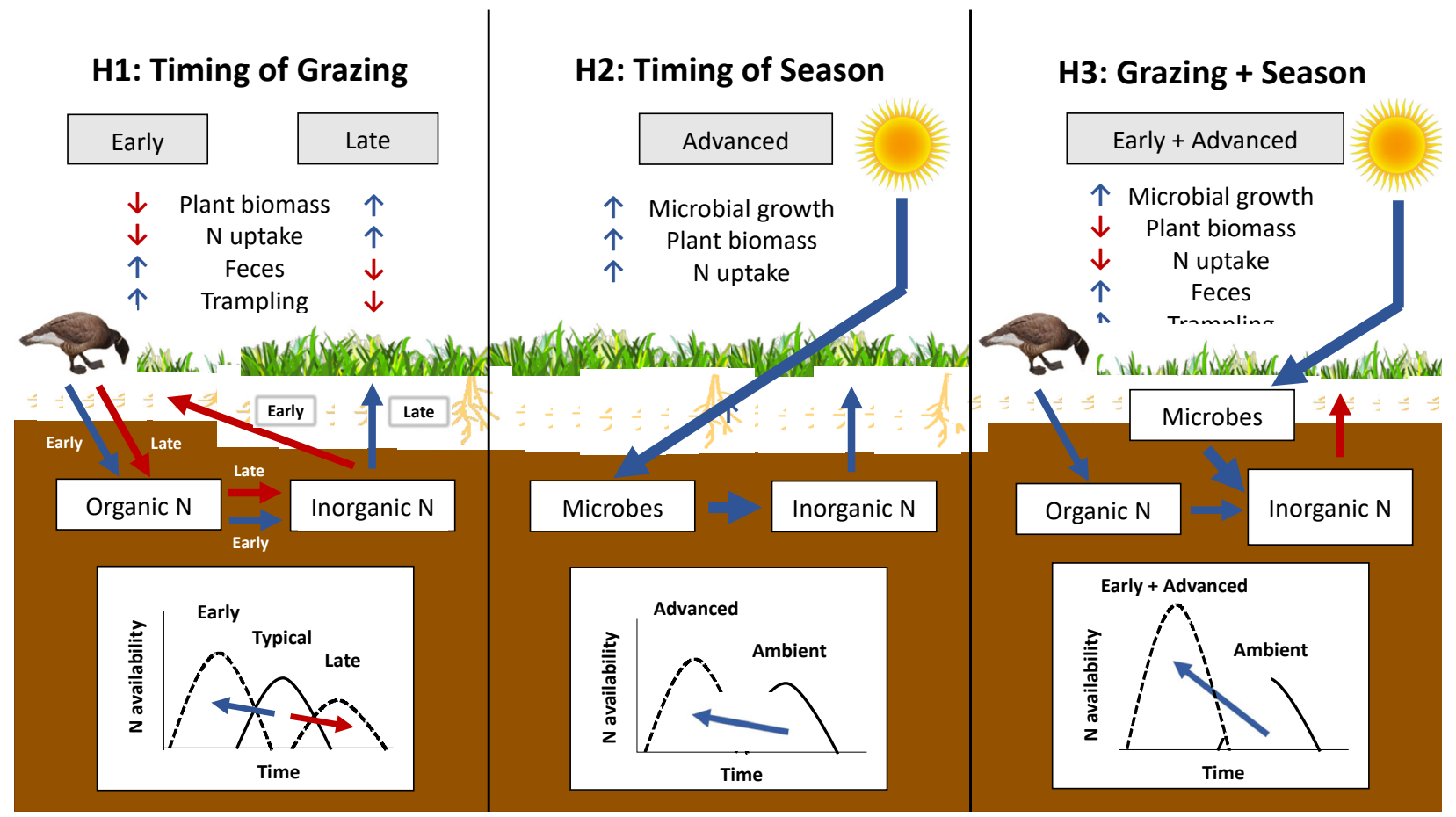

Figure 1. 

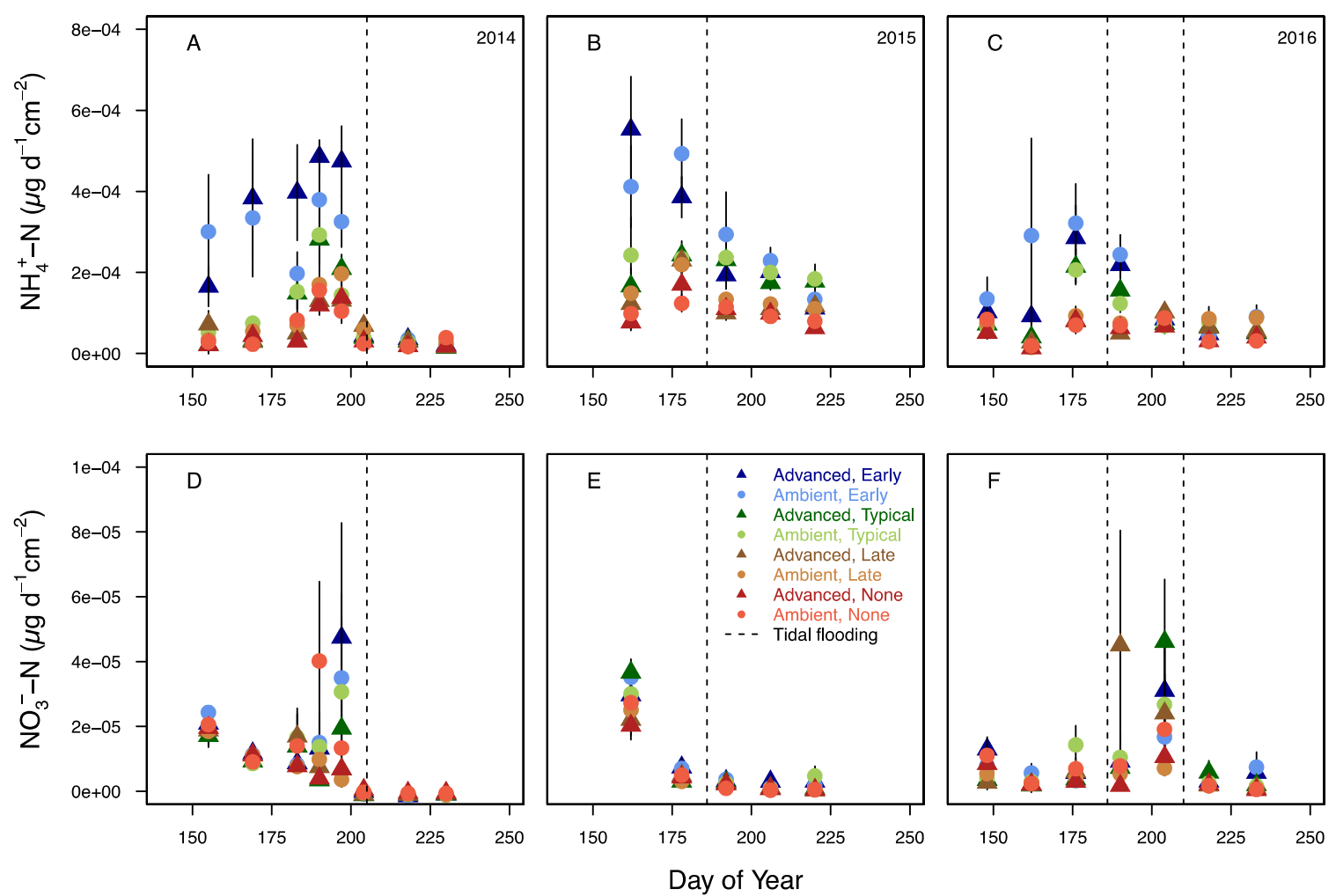

Figure 2. 

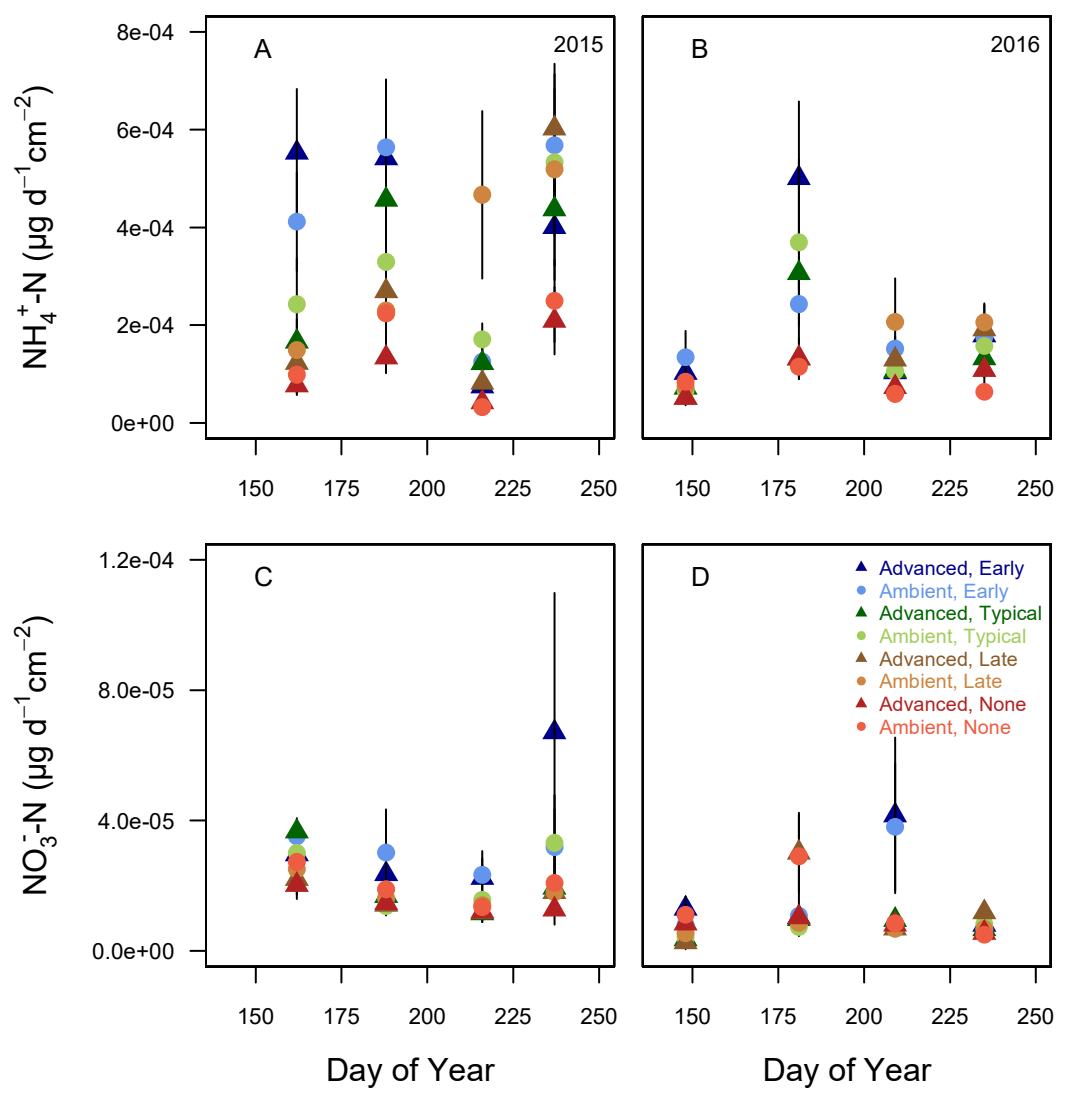

Figure 3. 

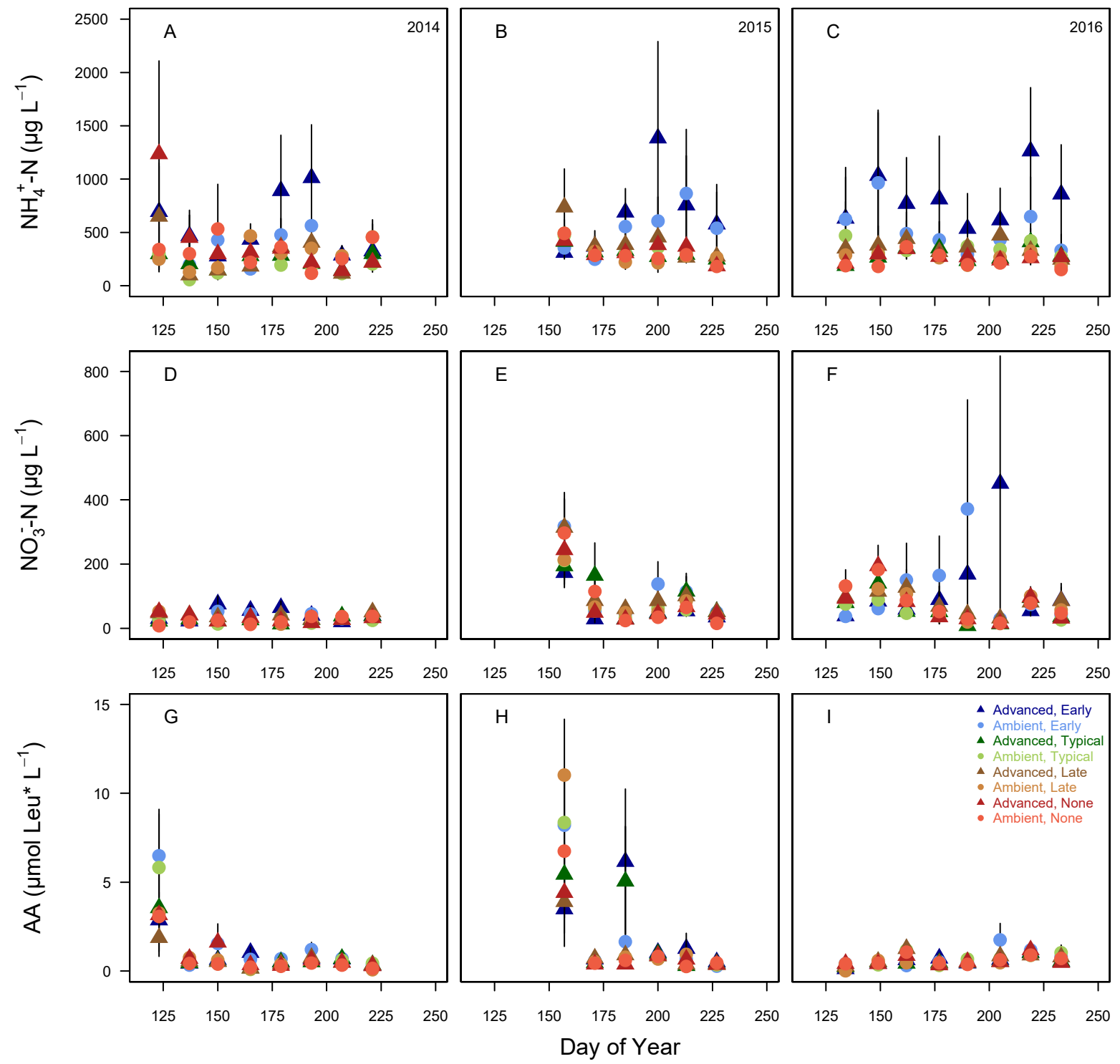

Figure 4. 


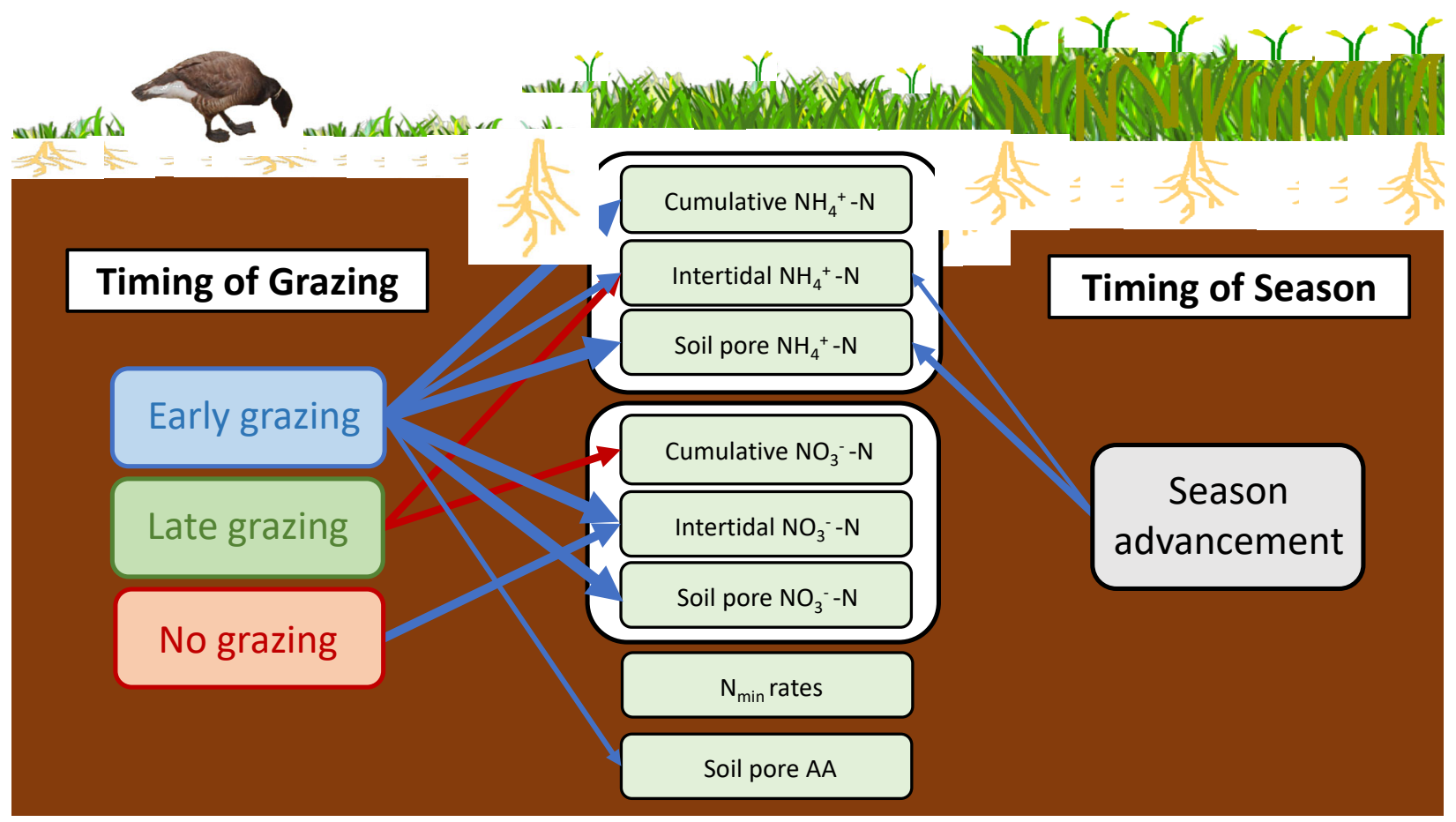

Figure 5. 